Current Research Journal of Social Sciences 10(1): 1-8, 2019

DOI:10.19026/crjss.10.5988

ISSN: 2041-3238, e-ISSN: 2041-3246

(C) 2019 Maxwell Scientific Publication Corp.

Submitted: June 27, $2018 \quad$ Accepted: September 7, 2018

Published: January 25, 2019

\title{
Research Article \\ Is Choice of Agricultural Technologies a Risk Management Strategy among Smallholder Farmers? Insights from Kenya
}

\author{
${ }^{1}$ Henry Mwololo and ${ }^{2}$ Rachel Ajambo \\ ${ }^{1}$ Department of Agricultural Economics, University of Nairobi, P.O Box 29053-00625 Nairobi, Kenya, \\ Tel.: +254 704073412 \\ ${ }^{2}$ Kilimo Trust-Tanzania, P.O Box 106217, Dar-es-Salaam, Tanzania
}

\begin{abstract}
This study addresses a gap in literature on the adoption of improved agricultural technologies as a risk management strategy using data from 599 households in Kenya who were exposed to fortified beans (Phaseolus vulgaris) and an improved indigenous chicken (Gallus gallus domesticus). This is because despite the rich literature on agricultural technology adoption, literature on technology adoption as a risk mitigation strategy is limited. Seventy-three per cent of farmers were non-adopters, $18 \%$ adopted the fortified beans, $3 \%$ adopted the improved indigenous chicken and 6\% adopted both technologies. Econometric results show that limited access to markets reduced adoption as marketing risks increase. Older farmers were more likely to adopt the fortified beans as they may be wealthier and generally knowledgeable about bean technology reducing their absolute risk averseness. Maleheaded households were more likely to adopt the improved chicken. Farm diversity, access to extension and being a group official increased adoption to spread risk. We concluded that farmers' choice of agricultural technologies is indeed a risk management strategy and therefore policies and technology promotion interventions should be riskresponsive.
\end{abstract}

Keywords: Choice, multinomial logit, multi-stage, risk, technologies

\section{INTRODUCTION}

Global food systems are highly vulnerable to risks such as unreliable rainfall and fluctuating market conditions (Ullah and Shivakoti, 2014). This vulnerability is further exacerbated by the fact that food systems depend on a small number of domesticated plant and animal species (Tung, 2017). Kahan (2013) categorizes agricultural risks into:

- Production risks due to erratic weather, pests and diseases

- Marketing risks due to uncertainties in market prices and cost of production

- Financial risks due to uncertainties about future interest rates

- Institutional risks due to unpredictable changes in the provision of services by markets and extension providers

- Human risks that are associated with poor health or even death

According to Bramoullé and Kranton (2007), many developing countries lack formal insurance mechanisms to manage risk. As a result, farmers make farming decisions to mitigate the adverse effects of risks. Farm diversification has been reported as one such risk management strategy (Ullah and Shivakoti, 2014; Rehima et al., 2013). Farm diversification is the cultivation and keeping of more than one crop and livestock enterprises, respectively and at the same time (Tangermann, 2011; Mishra et al., 2004). Kahan (2013) argues that farm diversification spreads risk because it is unlikely that multiple farm enterprises can be affected by changing conditions such as weather or markets in the same way.

Another common risk management decision and especially among smallholder farmers is mixed farming. According to the Food and Agriculture Organization (FAO) of the United Nations (FAO, 2001), mixed farming involves managing crop and livestock enterprises concurrently. One of the benefits of the mixed farming system is the symbiotic relationship between crops and livestock. For instance, while animal manure is a good source of plant nutrients, plant remains (e.g., straw) can be used as animal feed (FAO, 2001).

\footnotetext{
Corresponding Author: Henry Mwololo, Department of Agricultural Economics, University of Nairobi; P.O Box 29053-00625 Nairobi, Kenya, Tel.: +254 704073412

This work is licensed under a Creative Commons Attribution 4.0 International License (URL: http://creativecommons.org/licenses/by/4.0/).
} 
In this study, we hypothesise that farming systems are designed to triumph amidst risks. For example, a decision by farmers to manage a mix of crops and livestock enterprises or to choose either of them or even failure to adopt can be viewed as a risk mitigation strategy. We study two improved technologies: fortified KK15 beans (Phaseolus vulgaris) and cross-breed chicken (Gallus gallus domesticus). Since the two technologies were new in the study area, the issue of risk in their adoption is inevitable. The purpose of this study was to assess whether farmers' adoption decisions have a risk management bearing. Findings from this study will inform practitioners and policymakers in the design of interventions and policies that are risk responsive.

The $K K 15$ bean is enhanced with zinc ( $57.5 \mathrm{ppm})$ and iron $(631 \mathrm{ppm})$. These levels of zinc and iron are higher compared to those of most African bean cultivars that exhibit an average of $31 \mathrm{ppm}$ of zinc and $96.1 \mathrm{ppm}$ of iron (Kimani et al., 2006). While iron is responsible for the synthesis of haemoglobin, zinc is essential for human growth (Devi et al., 2014). Also, the $K K 15$ bean variety is resistant to root rot and bean rust, it is early maturing, fast cooking and is high yielding in low to medium altitude agro-ecological zones.

According to Fotsa and Ngeno (2011), Kuroiler chicken is a dual purpose cross-breed that can be kept under both free range and intensive production systems making it cost effective compared to pure hybrid chicken. The cross-breed is also high yielding producing up to 200 eggs per year compared to indigenous breeds that produce about 100 eggs per year. Moreover, the Kuroiler chicken can reach a live weight of $4 \mathrm{~kg}$ in six months while indigenous breeds can only weigh $1.5-2.5 \mathrm{~kg}$ within the same period.

\section{MATERIALS AND METHODS}

Theoretical framework: Farmers' decision to choose a particular agricultural technology can be analysed within the framework of benefit maximization. The two widely applied benefit maximization theories in agricultural technology adoption studies are random utility theory (RUT) and Expected Utility Theory (EUT) (Greene, 2012; Schoemaker, 1982). The two theories assume that given a set of alternatives, individuals choose the alternative that yields the highest benefit (Batz et al., 1999). The only difference between the two theories is that EUT applies when one's choice is stated while RUT applies when the choice of a decision maker is revealed (Polak and Liu, 2006). Farmers' adoption statuses in this study were observed and therefore we applied the RUT.

Given the two technologies (KK15 fortified beans and Kuroiler chicken), four technology choice options are possible:
- $\quad$ Choose the KK15 fortified beans

- Choose the Kuroiler chicken

- Choose both technologies, or

- Fail to adopt

If the benefits due to the above four choice options are $U_{b}, U_{c}, U_{b c}$ and $U_{n}$ respectively, the RUT suggests that a farmer will choose an alternative only if the specific choice yields the highest benefit.

Following Greene (2012), the choices can be specified as follows:

If $\mathrm{U}_{\mathrm{b}}>\mathrm{U}_{\mathrm{c}}$, the bean is chosen

If $\mathrm{U}_{\mathrm{b}}>\mathrm{U}_{\mathrm{bc}}$ bean is chosen

If $\mathrm{U}_{\mathrm{bc}}>\mathrm{U}_{\mathrm{n}}$ both technologies are chosen

Otherwise, none of the technologies is adopted

Empirical model: We observed farmers' behaviour for the four possible adoption options giving rise to unordered discrete outcome variable with four categories. According to Greene (2012), unordered categorical data can be analysed using the Multinomial Logit (MNL) and Multinomial Probit (MNP) models. Gujarati (2004) argues that MNL and MNP models yield similar estimates and therefore, the choice between them is only guided by the distribution of the error term. In the use of MNL, the error term is assumed to be logistically distributed (Greene, 2012). The main limitation of the MNL model is the independence of irrelevant alternatives (IIA) assumption which requires that the probability of choosing between alternatives should not change with the introduction of new alternatives. Providing alternatives that are absolutely different (as is the case in this study) renders the IIA assumption irrelevant.

In applying the MNP technique, the error term should be normally distributed and homoscedastic, otherwise, the estimates are inefficient (Greene, 2012). The more stringent normal distribution and homoscedasticity assumptions of the MNP model constraints its application in analysing cross-sectional data (Greene, 2012). The major strength of the MNP model is its ability to relax the IIA assumption. The error term in this study was not normally distributed and therefore, we apply the MNL model and modelled as shown below.

Following McFadden (1974), the probability that the $i^{\text {th }}$ farmer makes the $j^{\text {th }}$ choice is specified as:

$P_{i j}=\operatorname{Pr}\left(j \mid X_{i}\right)=\frac{\exp \left(\beta_{j} X x_{i}\right)}{\sum_{i=1}^{4} \exp \left(\beta_{n} X_{J}\right)} ; 0<P r_{i y}<1$ 
where, $\operatorname{Pr}\left(j \mid x_{i}\right)$ is the probability that the $i^{\text {th }}$ farmer makes the $j^{\text {th }}$ choice option $(J=4)$ and the probability takes a value $0>\operatorname{Pr}\left(j \mid x_{i}\right)>1, X_{i}$ are socio-economic and institutional factors associated with the $i^{\text {th }}$ farmer and $\beta_{j}$ is a vector of parameters to be estimated. Four estimations were possible in this study each corresponding to a choice alternative. Nevertheless, three equations were estimated, one for $K K 15$ fortified beans, the second estimation was for the Kuroiler chicken and a third for both technologies. The nonadoption choice was set as the base alternative against which parameter estimates for the other choices were interpreted because a majority (73\%) of the farmers failed to adopt.

Estimates by the MNL model do not directly explain the effect of the independent variables on the outcome variable but the relative odds because the resulting probability function is non-linear (Wulff, 2015). To measure the direct effect of a change in any of the explanatory variables on the dependent variable, marginal effects were computed by differentiating Eq. (2) (Bowen and Wiersema, 2004). Following Wulff (2015), the marginal effects were calculated as shown:

$$
M E_{i j}=\frac{\partial P_{i j}}{\partial x_{i j}}=\frac{\partial \operatorname{Pr}\left(j \mid x_{i}\right)}{\partial x_{i j}}=P_{i j}\left(\beta_{k j}-\bar{\beta}_{i}\right) \text { for continuous }
$$

independent variables

$M E_{i j}=\operatorname{Pr}\left(x_{i}=1\right)-\operatorname{Pr}\left(x_{i}=0\right)$ for dummy independent variables

where, $M E_{i j}$ is the marginal effect and $\bar{\beta}_{i}$ is the weighted probability of the coefficients for the different choice combinations. The rest of the parameters are defined in the same way as in Eq. (2).

The equation that was estimated using the MNL model to assess the drivers of the four choice decisions is given Eq. (8):

enterprise choice $=f$ (title deed ownership, distance to tarmac, distance to input market, access to extension, off-farm income, household size, gender, age, education, access to credit, farm size, farm diversity, climatic shocks, biological shocks, economic shock, membership to multiple groups) $+e$

Definition of variables used in the empirical model: The dependent variable in this study was choice measured as non-adoption $=0 ; K K 15$ fortified beans $=$ 1 ; cross-breed chicken $=2$ and both $=3$. The independent variables, their units of measurement and $a$ priori signs are summarised in Table 1.

Distance to market significantly influences technology adoption. According to Nazziwa-Nviiri et al. (2017), an extra kilometre away from market reduced the likelihood of fertilizer adoption by 1.1 percentage points in Uganda. A negative effect of distance to market on technology adoption is hypothesised in this study. Access to extension services was measured as a dummy variable. A study by Njuguna et al. (2017) found that access to extension services positively and significantly influenced the adoption and intensity of adoption of brooding technologies in Kenya. Similar findings were reported by Tamir et al. (2015) in Ethiopia. According to Noltze et al. (2011), off-farm income increases the likelihood of technology adoption. However, findings in the same study show that off-farm income had no effect on the intensity of technology adoption. We hypothesise that off-farm income would increase technology adoption as farmers are able to afford the cost associated with technology adoption.

According to Nguyen-Van et al. (2016), household size has a negative effect on the choice of technologies. A member's increase in household size reduced the likelihood of choosing old-green and new-old-green tea varieties by 81.8 and 66.3 percentage points, respectively in Vietnam. Similar negative association between household size and choice of adaptation strategies to climate change was reported by Obayelu et al. (2014) in Nigeria. However, Ayuya et al. (2012) found that a member's increase in household size increased the likelihood of adopting farmyard manure by 3.7 percentage points in Kenya. Due to contradicting findings, we are not able to predict the

Table 1: Definition of variables used in the multinomial estimation

\begin{tabular}{llc}
\hline Dependent variable & Unit of measurement & Expected sign \\
\hline Technology choice & $0=$ non-adoption; $1=$ KK15 fortified beans; 2 = cross-breed chicken; 3 = Both \\
Independent variables & Unit of measurement & - \\
Distance to market (km) & Kilometres & + \\
Access to extension (dummy) & $0=$ No; $1=$ Yes & + \\
Off-farm income (dummy) & $0=$ No; $1=$ Yes & \pm \\
Household size (number) & Number of members & \pm \\
Gender of household head (dummy) & $0=$ Female; 1 = Male & \pm \\
Age of household head (years) & Years & + \\
Education of household head (years) & Years & + \\
Access to credit (dummy) & $0=$ No; $1=$ Yes & - \\
Farm size (hectares) & Hectares & - \\
Farm diversity (number) & Number of enterprises & + \\
Group official (dummy) & $0=$ No; $1=$ Yes & + \\
\hline
\end{tabular}

(+) implies more likely to adopt; (-) implies more likely to adopt both technologies 
effect of household size on technology choice in this study. Gender of household head was captured as a dummy variable. Nazziwa-Nviiri et al. (2017) found that female-headed households were 20 percentage points less likely to adopt fertilizer technology due to resource inequities between men and women in Uganda. However, Simtowe et al. (2016) found a positive association between female-headed households and pigeon pea adoption in Malawi.

Literature is inconsistent on the effect of age on technology adoption. Ayuya et al. (2012) found that a year's increase in farmers' age increased the likelihood of choosing crop residue as an organic soil management practice by one percentage point but reduced the likelihood of choosing farmyard manure by 1.3 percentage points in Nigeria. Similarly, Murage and Ilatsia (2011) found that a year's increase in farmers' age reduced the likelihood of choosing artificial and natural insemination services for dairy cows by 0.7 percentage points compared to artificial insemination in Kenya. Due to literature discrepancies, we do not hypothesise the effect of age.

Education of household head was measured in years. According to Matsumoto et al. (2013), a years' increase in education of household head increased adoption of planting fertilizer by 0.133 units in Uganda indicating that educated farmers were more willing to use modern inputs. Similarly, Obisesan et al. (2016) found that an increase in farmers' education increased cassava adoption by 17.5 percentage points in Nigeria. Access to credit was measured as a dummy and a positive association with choice of new technologies hypothesised following Obisesan et al. (2016) who found that access to credit increased intensity of adoption of cassava varieties by 15.8 percentage points in Nigeria.

Farm size plays a critical role in the choice of agricultural technologies. Some studies have reported a positive effect of farm size on technology adoption as farmers with large farm sizes incur less opportunity cost of land (Abay et al., 2016). Similarly, Chuchird et al. (2017) found a positive effect of farm size on the choice of irrigation technologies in Thailand where a hectare's increase in farm size increased adoption of water wheel technology by 55.6 percentage points. Consequently, we hypothesise a positive association between farm size and technology choice.

Farm diversity was measured as the number of enterprises (crop and livestock) a household was managing in the year preceding the survey for this study. Ali (2015) reports that farm diversity is a risk management strategy. As a result, we hypothesise that farmers who are diversified are more likely to diversify further to spread risks even more. Group official was a dummy variable and a positive association with technology choice was hypothesised.
Study area: This study was carried out in Nyamira and Kisii Counties, Kenya where the beans and chicken technologies were promoted in 2016. Nyamira County lies between latitude 00 30' and 00 45' South and longitude 34 45' and 35 00' East with a population density of 656 persons $/ \mathrm{km}^{2}$ (Commission on Revenue Allocation, 2011). Ninety per cent of the County's land is arable. Coupled with reliable rainfall of $1200 \mathrm{~mm}$ $2100 \mathrm{~mm}$ per year makes agriculture the major economic activity. Farmers are largely smallholders managing plots of approximately 0.97 Ha owing to the high population density.

Kisii County lies between latitude 0 30' and 10 ' South and longitude 34 38' and 35 0' East and has a population density of 595 persons $/ \mathrm{km}^{2}$ (Commission on Revenue Allocation, 2011). With 95\% of the County's land being arable and reliable rainfall of about 1,500 $\mathrm{mm}$ per year, agriculture is the mainstay of the County. Smallholder farming is common with household farm size of approximately $0.81 \mathrm{Ha}$ due to the high population density.

The choice of the two Counties was informed by the paradox of 'reliable agricultural conditions and malnutrition in the same area'. Smale et al. (2011) argue that such paradoxes could be due low technology adoption which is a common phenomenon in SSA anyway. According to the Kenya National Bureau of Statistics (KNBS, 2015), about 26 percent of children in the two Counties under the age of five years is stunted. Moreover, agricultural extension systems often promote productivity-enhancing technologies leaving out the equally important nutrition-enhancing technologies. This suggests that promotion of nutrition-enhancing technologies such as fortified beans and their subsequent adoption can significantly reduce malnutrition.

Sampling procedure and data: This study used crosssectional data collected in October-December 2016. Multi-stage sampling procedure was used to select 599 households. In the first stage, a list of 94 farmers' groups (71 from Kisii and 23 from Nyamira) was constructed from existing registered farmers' groups. Considering the proportion of farmers' groups in each County, the second stage involved the use of simple random sampling to select 48 groups (32 from Kisii County and 16 from Nyamira County). In the third stage, simple random sampling was used to select 13 farmers from each of the selected groups. A total of 599 farmers were surveyed and included in this analysis.

\section{RESULTS AND DISCUSSION}

Farmer and farm characteristics: Farmer and farm characteristics of the respondents are summarized in Table 2. The average farm size was 0.39 ha although adopters had slightly larger farms compared to non- 
Curr. Res. J. Soc. Sci., 10(1): 1-8, 2019

Table 2: Farmer characteristics

\begin{tabular}{llll}
\hline Independent variables & Non-adopters $(\mathrm{n}=407)$ & Adopters $(\mathrm{n}=152)$ & Pooled $(\mathrm{n}=599)$ \\
\hline Farm size (hectares)* & $0.38(0.01)$ & $0.41(0.02)$ & $0.39(0.01)$ \\
Distance to market $(\mathrm{km})^{* *}$ & $4.13(0.13)$ & $3.56(0.20)$ & $3.97(0.11)$ \\
Off-farm income (dummy) & $0.83(0.02)$ & $0.82(0.03)$ & $0.83(0.02)$ \\
Household size (number) & $5.25(0.08)$ & $5.35(0.14)$ & $5.28(0.07)$ \\
Gender of household head (dummy) & $0.71(0.02)$ & $0.78(0.03)$ & $0.73(0.02)$ \\
Age of household head (years)** & $49.82(0.60)$ & $52.49(0.97)$ & $50.54(0.51)$ \\
Education of household head (years) & $9.21(0.14)$ & $9.70(0.24)$ & $9.35(0.12)$ \\
Access to credit (dummy) & $0.35(0.02)$ & $0.40(0.04)$ & $0.36(0.02)$ \\
Farm diversity (number) & $13.33(0.18)$ & $15.36(0.29)$ & $13.89(0.16)$ \\
Group official (dummy)** & $0.40(0.02)$ & $0.53(0.04)$ & $0.43(0.02)$ \\
Access to extension (dummy)*** & $0.64(0.02)$ & $0.84(0.03)$ & $0.69(0.02)$ \\
\hline
\end{tabular}

$* * *, * *$, and $*$ : denotes significance levels at $1 \%, 5 \%$ and $10 \%$ respectively

Table 3: Determinants of enterprise choice by smallholder farmers in Kenya

\begin{tabular}{|c|c|c|c|}
\hline \multirow[b]{2}{*}{ Control variables } & \multicolumn{3}{|c|}{ Marginal effects } \\
\hline & KK15 fortified beans $(\mathrm{n}=103)$ & Cross-breed Kuroiler chicken $(\mathrm{n}=17)$ & Both technologies $(\mathrm{n}=32)$ \\
\hline Farm size (hectares) & $-0.040(-0.46)$ & $0.032(1.33)$ & $-0.039(-1.27)$ \\
\hline Distance to market (km) & $-0.020 * * *(-3.02)$ & $-0.000(-0.14)$ & $-0.000(-0.10)$ \\
\hline Off-farm income (dummy) & $0.056(1.48)$ & $-0.003(-0.17)$ & $-0.021(-1.34)$ \\
\hline Household size (number) & $-0.009(-0.82)$ & $-0.002(-0.74)$ & $0.004(1.26)$ \\
\hline Gender (dummy) & $0.027(0.70)$ & $0.031^{* * *}(2.48)$ & $0.005(0.55)$ \\
\hline Age (years) & $0.004 * * *(2.95)$ & $-0.000(-0.23)$ & $-0.000(-0.68)$ \\
\hline Education (years) & $0.000(0.06)$ & $0.001(0.78)$ & $0.001(0.71)$ \\
\hline Access to credit (dummy) & $-0.037(-1.14)$ & $0.017(1.23)$ & $0.008(0.70)$ \\
\hline Farm diversity (number) & $0.017 * * *(3.74)$ & $0.000(0.07)$ & $0.005^{* * *}(2.97)$ \\
\hline Group official (dummy) & $0.065 *(1.88)$ & $-0.007(-0.69)$ & $0.017(1.50)$ \\
\hline Access to extension (dummy) & $0.088^{* * *}(2.69)$ & $0.009(0.83)$ & $0.045^{* * *}(3.38)$ \\
\hline Observations & 559 & & \\
\hline Wald test & $109.87 * * *$ & & \\
\hline Pseudo $\mathrm{R}^{2}$ & 0.1159 & & \\
\hline Log pseudo likelihood & -400.24 & & \\
\hline
\end{tabular}

adopters. Distance to market was $3.97 \mathrm{~km}$ and adopters were closer to the nearest market by half a kilometre relative to non-adopters. Farmers were middle-aged (50.54 years) and adopters were significantly older. A majority (53 percent) of adopters were group officials while access to extension ranged from 64 percent among non-adopters to 84 percent among adopters and the difference was significant at the one per cent level.

Econometric results: The econometric results are presented in Table 3 . The data $(y \mid x)$ was logistically distributed (Jarque-Bera statistic was significant at the one per cent level) and therefore multinomial logit model was appropriate. The Wald statistic was significant at the one per cent level and the pseudo $\mathrm{R}^{2}$ was 11.9 percent suggesting that the model fitted the data well. Moreover, 5 out of the 11 independent variables included in the model were highly significant, implying high prediction power of the model.

The independent variables were tested for multicollinearity using the Variance Inflation Factor (VIF) and the Pearson correlation statistics. The results show that the explanatory variables did not exhibit multicollinearity (all the coefficients of the VIF and the Pearson tests were less than 10 and 0.5 , respectively). Seventy-three per cent of farmers were non-adopters, 18 percent adopted fortified beans, 3 percent adopted Kuroiler chicken and 6 percent adopted both technologies.
Distance to market was negatively and significantly associated with the choice of the fortified beans and the estimate was significant at the one per cent level (Table 3). A kilometre increase in distance to the nearest market decreased the likelihood of choosing the fortified beans by 2 percentage points. This finding implies that as the distance to market increases, farmers are less likely to adopt fortified beans. Long distance to market limits market access due to the resulting higher costs and more time required in market participation. By reducing their likelihood of adopting the fortified beans, this decision can be viewed as a risk management strategy where farmers consider the positive role of proximity to markets in increasing profit from the sale of beans.

Gender of the household head had a positive and significant effect on the choice of Kuroiler chicken (Table 3). Male-headed households were more likely to adopt Kuroiler chicken by 3 percentage points compared to female-headed households and the estimate was significant at the one per cent level. The effect of gender is against our hypothesised direction that men would be less likely to adopt chicken because chicken is perceived to be a women's enterprise (Akite et al., 2018). However, studies have shown that as income from agricultural enterprises increase, management of those enterprises and revenues 
thereafter tend to shift from women to men (Ogutu et al., 2017). This explains the observation that men were more likely to adopt Kuroiler given its higher cost of adoption and expected higher returns relative to local breeds. This finding contradicts Kabunga et al. (2012) who found that female-headed households were more likely to adopt tissue culture bananas in Kenya if they are provided with similar adoption conditions as men.

Age of the household head had a positive and significant effect on the choice of KK15 fortified beans at the one per cent level (Table 3). A year's increase in age increased the probability of adopting the fortified beans by 0.4 percentage points. McNamara and Weiss (2005) provide a rational explanation for this observation by arguing that as age advances, farmers are more likely to accumulate wealth decreasing their absolute risk averseness. This would lead to an increase in adoption by older farmers as observed in this study. Moreover, beans have been grown in the study area since time immemorial and therefore older farmers may understand the management of beans enterprises than younger farmers, posing minimal production risks.

Farm diversity is a risk management strategy (Agyeman et al., 2014; Akaakohol and Aye, 2014). This study found that households that were already diversified were more likely to choose fortified beans and both technologies by 1.7 and 0.5 percentage points respectively and the estimates were significant at the one per cent level (Table 3). This implies that farm diversity encourages further diversification explaining the positive association between the two adoption options. This is because farm diversification is a strategy for spreading risk as multiple enterprises may not be affected in the same manner by risks (Kahan, 2013).

Access to extension services had a positive and significant effect on the adoption of KK15 fortified beans and both technologies at the one per cent level (Table 3). Farmers who accessed extension services were more likely to adopt the $K K 15$ fortified beans by 8.8 percentage points and both technologies by 4.5 percentage points, holding other factors constant. Extension creates awareness regarding existing and new technologies. Moreover, extension services provide farmers with the skills required in managing agricultural enterprises possibly explaining the positive association. By choosing the fortified beans or even both technologies, it is likely that farmers intend to take advantage of indigenous knowledge to manage production and marketing risks. Moreover, for the case of marketing risks such as poor prices, the two technologies can be kept for future markets or even consumed at home.

Although significant only at the 10 percent level, being a group official increased the probability of choosing KK15 fortified beans by 6.5 percentage points. Group officials are often of higher social status in many spheres including education, wealth and social networks. Kabunga et al. (2012) argue that information flows on agricultural technologies tend to favour community leaders because they play a linking role between change agents and the target communities. From a risk management perspective, group officials are often innovators and therefore, risk-loving further supporting the positive observation.

\section{CONCLUSION}

Previous studies have analysed the determinants of technology adoption (Pindiriri, 2018; Langat et al., 2013; Asfaw et al., 2011). However, none of them analyses the choice of agricultural technologies as a risk management strategy among smallholder farmers which we do in this article. We answer the question: is the choice of agricultural technologies a risk management strategy among smallholder farmers? Evidence was generated using cross-sectional data from 599 households.

Applying the multinomial logit model, we show that indeed, farmers' choice of agricultural technologies is aimed at managing risks inherent in smallholder agriculture systems. Farmers' choice of agricultural technologies had a plausible bearing about risk management. For example, farmers further from markets are less likely to adopt fortified beans because of limited market access that leads to higher marketing risks. Older farmers are more likely to adopt fortified beans given that they may be wealthier and knowledgeable about beans management reducing their absolute risk averseness. We also show that farmers with higher farm diversity are more likely to diversify even further which we interpret as a strategy to spread risk.

Overall, we conclude that farmers' choice of agricultural technologies is aimed at managing risks. An important policy implication is that considering the risks inherent in smallholder agriculture is a key strategy in developing risk-sensitive policies regarding new agricultural technologies. The findings also indicate that socio-economic and institutional attributes of farmers influence their choices amidst risks with a clear aim of managing those risks. We conclude that choice of agricultural technologies is farmer specific and therefore, practitioners should tailor interventions that promote new agricultural technologies to address farmers' individual motives of managing risks.

\section{ACKNOWLEDGMENT}

This research was funded by the German Federal Ministry of Food and Agriculture (BMEL) grant number 2813FSNu01.

\section{CONFLICT OF INTEREST}

We declare no conflict of interest in this study whatsoever. 
Curr. Res. J. Soc. Sci., 10(1): 1-8, 2019

\section{REFERENCES}

Abay, K.A., G. Berhane, A.S. Taffesse, B. Koru and K. Abay, 2016. Understanding Farmers' Technology Adoption Decisions: Input Complementarity and Heterogeneity. ESSP Working Paper 82, pp: 1-22.

Agyeman, B.A.S., S. Asuming-Brempong and E.E. Onumah, 2014. Determinants of income diversification of farm households in the western region of Ghana. Quart. J. Int. Agri., 53(1): 55-72.

Ali, J., 2015. Adoption of diversification for risk management in vegetable cultivation, Int. J. Veg. Sci., 21(1): 9-20.

Akaakohol, M.A. and G.C. Aye, 2014. Diversification and farm household welfare in Makurdi, Benue State, Nigeria. Develop. Stud. Res., 1(1): 168-175.

Akite, I., I.P. Aryemo, E.K. Kule, B. Mugonola, D.R. Kugonza and M.W. Okot, 2018. Gender dimensions in the local chicken value chain in northern Uganda. Afri. J. Sci. Technol. Innovat. Develop., 10(3): 1-14.

Asfaw, S., B. Shiferaw, F. Simtowe and M.G. Haile, 2011. Agricultural technology adoption, seed access constraints and commercialization in Ethiopia. J. Develop. Agri. Econ., 3(9): 436-447.

Ayuya, O.I., W.S. Kenneth and G.O. Eric 2012. Multinomial logit analysis of small-scale farmers' choice of organic soil management practices in Bungoma County, Kenya. Curr. Res. J. Soc. Sci., 4(4): 314-322.

Batz, F.J., K.J. Peters and W. Janssen, 1999. The influence of technology characteristics on the rate and speed of adoption. Agri. Econ., 21(2): 121130.

Bowen, H.P. and M.F. Wiersema, 2004. Modelling limited dependent variables: Methods and guidelines for researchers in strategic management. Res. Methodol. Strat. Manage., 1: 87-134.

Bramoullé, Y. and R. Kranton, 2007. Risk-sharing networks. J. Econ. Behav. Organiz., 64(3-4): 275294.

Chuchird, R., N. Sasaki and I. Abe, 2017. Influencing factors of the adoption of agricultural irrigation technologies and the economic returns: A case study in Chaiyaphum Province, Thailand. Sustainability, 9(9): 1524.

Commission on Revenue Allocation, 2011. Kenya County Fact Sheet. Retrieved form: http://siteresources.worldbank.org/INTAFRICA/Re sources/257994-

1335471959878/Kenya_County_Fact_Sheets_Dec 2011.pdf.

Devi, C.B., T. Nandakishore, N. Sangeeta, G. Basar, N.O. Devi and et al., 2014. Zinc in human health. J. Dental Med. Sci., 13(7): 18-23.
Food and Agriculture Organization (FAO), 2001. Mixed crop-livestock farming. A review of traditional technologies based on literature and field experience. Animal Production and Health Papers, pp: 152, ISBN 92-5-104576-3. Retrieved form: http://www.fao.org/docrep/004/Y0501E/y0501e00. htm.

Fotsa, J.C. and K. Ngeno, 2011. Pan African conference on the launch of the Kuroiler chicken. Int. Network Family Poul. Develop., 20(2): 40-55.

Greene, H.W. 2012. Econometric Analysis. 7th Edn., Pearson Education, Inc., Publishing as Prentice Hall, One Lake Street, Upper Saddle River, NJ 07458.

Gujarati, D.N. 2004. Basic Econometrics. 4th Edn., Tata McGraw-Hill Publishing Company Limited. New Delhi, India, pp: 580-625.

Kabunga, N.S., T. Dubois and M. Qaim, 2012. Heterogeneous information exposure and technology adoption: The case of tissue culture bananas in Kenya. Agri. Econ., 43(5): 473-486.

Kahan, D., 2013. Farm Management Extension Guide. Managing Risk in Farming. Retrieved form: http://www.fao.org/uploads/media/3-

ManagingRiskInternLores.pdf.

KNBS (Kenya National Bureau of Statistics), 2015. Kenya Demographic and Health Survey 2014. Retrieved form: https://dhsprogram.com/pubs/pdf/fr308/fr308.pdf.

Kimani, P.M., E. Karuri and S. Mwaura, 2006. Iron, Zinc and Protein Concentration in African Bean Cultivars. Annual Report-Bean Improvement Cooperative, 49: 155.

Langat, B.K., V.K. Ngéno, P.M. Nyangweso, M.J. Mutwol, L. Gohole and S. Yaninek, 2013. Drivers of technology adoption in a subsistence economy: The case of tissue culture Bananas in Western Kenya. Proceeding of the 4th International Conference of the African Association of Agricultural Economists.

Matsumoto, T., T. Yamano and D. Sserunkuuma, 2013. Technology adoption and dissemination in agriculture: Evidence from sequential intervention in maize production in Uganda. GRIPS Discussion Paper No. 13-14. National Graduate Institute for Policy Studies. Retrieved form: https://core.ac.uk/download/pdf/51221422.pdf.

McFadden, D., 1974. Conditional Logit Analysis of Qualitative Choice Behaviour. In: Zarembka, P. (Ed.), Frontiers in Econometrics, Academic Press, New York, pp:105-145.

McNamara, K.T. and C. Weiss, 2005. Farm household income and on-and off-farm diversification. J. Agri. Appl. Econ., 37(1): 37-48. 
Mishra, A.K., H.S. El-Osta and C.L. Sandretto, 2004. Factors affecting farm enterprise diversification. Agri. Finance Rev., 64(2): 151-166.

Murage, A.W. and E.D. Ilatsia, 2011. Factors that determine use of breeding services by smallholder dairy farmers in Central Kenya. Trop. Animal Health Prod., 43(1): 199-207.

Nazziwa-Nviiri, L., B. Van Campenhout and D. Amwonya, 2017. Stimulating agricultural technology adoption: Lessons from fertilizer use among Ugandan potato farmers. Int. Food Pol. Res. Inst., 1608: 36.

Nguyen-Van, P., C. Poiraud and N. To-The, 2016. Modelling farmers' decisions on tea varieties in Vietnam: A multinomial logit analysis. Agri. Econ., 48(3): 291-299.

Njuguna, C.K., L.W. Kabuage and E.K. Bett, 2017. Determinants of adoption and intensity of use of brooding technology in Kenya: The case of indigenous chicken farmers in Makueni and Kakamega Counties, Kenya. Afri. J. Agri. Econ. Rural Develop., 5(2): 532-538.

Noltze, M., S. Schwarze and M. Qaim, 2011. Understanding the adoption of systemic innovations in smallholder agriculture: The System of Rice Intensification (SRI), Timor Leste. Proceeding of the Presentation at the EAAE 2011 Congress, Vol. 30.

Obayelu, O.A., A.O. Adepoju and T. Idowu, 2014. Factors influencing farmers' choices of adaptation to climate change in Ekiti State, Nigeria. J. Agri. Environ. Int. Develop. (JAEID), 108(1): 3-16.

Obisesan, A., T.T. Amos and R.J. Akinlade, 2016. Causal effect of credit and technology adoption on farm output and income: The case of cassava farmers in Southwest Nigeria. Proceeding of the AAAE 5th International Conference, September 23-26, 2016, Addis Ababa, Ethiopia (No. 246443). African Association of Agricultural Economists (AAAE).

Ogutu, S.O., T. Gödecke and M. Qaim, 2017. Agricultural commercialization and nutrition in smallholder farm households (No. 97). GlobalFood Discussion Papers. Retrieved form: https://www.econstor.eu/bitstream/10419/161624/1 /887660525.pdf.

Pindiriri, C., 2018. Breaking the Traditional Trap: Assessing Drivers of Modern Technology Adoption by Smallholder Farmers in Hurungwe District, Zimbabwe. In: Shimeles, A., A. VerdierChouchane and A. Boly (Eds.): Building a Resilient and Sustainable Agriculture in SubSaharan Africa. Palgrave Macmillan, Cham, pp: 33-53.
Polak, S. and X. Liu, 2006. From Random Utility to Random Expected Utility: Theory and Application to Departure Time Choice. European Transport Conference (ETC) Association for European Transport.

Rehima, M., K. Belay, A. Dawit and S. Rashid, 2013. Factors affecting farmers' crops diversification: Evidence from SNNPR, Ethiopia. Int. J. Agri. Sci., 3(6): 558-565.

Schoemaker, P.J.H., 1982. The expected utility model: Its variants, purposes, evidence and limitations. J. Econ. Literat., 20(2): 529-563.

Simtowe, F., S. Asfaw and T. Abate, 2016. Determinants of agricultural technology adoption under partial population awareness: The case of pigeon pea in Malawi. Agri. Food Econ., 4(1): 121.

Smale, M., D. Byerlee and T. Jayne, 2011. Maize Revolutions in Sub-Saharan Africa. In: Otsuka, K. and D. Larson (Eds.): An African Green Revolution. Springer, Dordrecht, pp: 165-195.

Tamir, S., F. Moges, Y. Tilahun and M Hile 2015. Determinants of adoption of exotic poultry breeds among smallholder poultry producers in North Western Amahara Region, Ethiopia. Global Sci. Res. J., 3(6): 162-168.

Tangermann, S., 2011. Risk management in agriculture and the future of the EU's common agricultural policy. Int. Centre Trade Sustain. Develop., pp: 34.

Tung, D.T., 2017. Measurement of on-farm diversification in Vietnam. Outlook Agri., 46(1): 312.

Ullah, R. and G.P. Shivakoti, 2014. Adoption of onfarm and off-farm diversification to manage agricultural risks: Are these decisions correlated? Outlook Agri., 43(4): 265-271.

Wulff, J.N., 2015. Interpreting results from the multinomial logit model: Demonstrated by foreign market entry. Organiz. Res. Methods, 18(2): 300325. 